\section{Virology}

\section{A new human herpesvirus}

\section{From Robin Weiss and Carel Mulder}

IN this week's Science (234, 596 and 601; 1986), two papers describe a hitherto unknown herpesvirus isolated from six patients with lymphoma or lymphoproliferative disorders. Zaki Salahuddin, in Robert Gallo's laboratory, first observed some odd-looking giant cells in short-term cultures of peripheral blood leukocytes from three patients with different types of lymphoma - an acquired immunodeficiency syndrome (AIDS)-related B-cell tumour, a cutaneous T-cell lymphoma and an immunoblastic lymphoma. These cells expressed viral antigens. The same virus was subsequently isolated from three further patients, two with lymphadenopathy and one with T-cell acute lymphocytic leukaemia.

Morphologically, the virus particles have the typical appearance of herpesviruses, being $200 \mathrm{~nm}$ in diameter, with an outer envelope loosely surrounding an icosahedral nucleocapsid. The genome is a large one (more than 110 kilobases of double-stranded DNA) and thus in the range of other herpesviruses (100-220 kb). A 9-kb probe developed from the new virus did not hybridize with any of the known human herpesviruses (EpsteinBarr virus, cytomegalovirus, herpes simplex viruses and varicella-zoster virus). The new virus is also serologically unrelated to other primate herpesviruses.

Replication of the virus appears to be restricted to freshly cultivated $\mathrm{B}$ cells and for this reason the discoverers have named the virus human B-lymphotropic virus (HBLV). One wonders what these or other investigators will call a human Blymphotropic retrovirus if such a virus comes to light one day. HBLV does not appear to transform or immortalize B cells, and the isolation of the virus from 3 out of 6 patients with T-cell neoplasia or lymphadenopathy should lead to caution about an aetiological role for this Blymphotropic virus in the lymphoproliferative disorders described. Two of the six patients were also infected with the AIDS virus (human immunodeficiency virus, HIV), one suffering from AIDS itself, but Salahuddin et al. promise further seroepidemiological data indicating that the risk groups for $\mathrm{HBLV}$ infection are not wholly coincident with HIV. They imply that AIDS-related lymphoma may be aetiologically linked with HBLV. Among 220 healthy donors, only 4 were HBLV seropositive, contrasting with the high prevalence of EBV infection world-wide.

HBLV is the first human herpesvirus to be discovered since Epstein, Achong and Barr observed the Epstein-Barr virus in electron micrographs of cultured Burkitt's lymphoma cells. Lymphoproliferative herpesviruses of new world monkeys, of rabbits and of chickens have been described. The present papers mark just the beginning of investigations into the molecular and cell biology, epidemiology and pathogenesis of HBLV. Once again, Gallo and his team have published provocative new data that will keep many investigators busy for some time to come.

We wonder whether there are more herpesviruses lurking in the human population. The agents of Hodgkin's disease and Kaposi's Sarcoma would be plausible candidates. The search for viral agents is given further impetus by the report on page 814 of this issue (Nature 323, 814; 1986) of retroviral association with Kawasaki disease.

Robin Weiss is at the Institute of Cancer Research, London SW3 6JB; Carel Mulder is on a sabbatical visit from the Department of Pharma cology, University of Massachusetts Medical School, Worcester, Massachusetts 01602, USA.

\title{
The demise of a living fossil?
}

ONE of the best-known examples of a living fossil is the tuatara Sphenodon punctatus, found in New Zealand (see figure). Sphenodon looks like a medium-sized lizard, but its skull and skeleton appear to reveal primitive characters that have been lost by lizards. It is often said to have remained unchanged from its ancestors of over $\mathbf{2 0 0}$ million years ago, but new research ${ }^{1-3}$ suggests that Sphenodon is not as archaic as has been assumed.

What is a living fossil? A common view, stemming from Darwin ${ }^{4}$, is that living fossils are lineages that have survived for a long time and have evolved very slowly, mainly because of the absence of biological competition. Schopf ${ }^{5}$, on the other hand, argues that living fossils probably do not exist as most examples either lack a fossil record or there is no evidence that the extinct forms really are the same as their supposed ancestors.

Although there are no known fossil specimens of Sphenodon ${ }^{5}$, how similar is it to the fossil sphenodontians? The earliest known sphenodontians occurred in the late Triassic, about 225 million years ago $^{1,3}$. Some of these animals, varying in body length from 15 to $35 \mathrm{~cm}$, had snouts and multiple rows of teeth all over the bones of the palate, whereas others had fewer rows of teeth and longer snouts. Most of these early sphenodontians had teeth fused to the bones of the jaw (the acrodont condition, typical of Sphenodon) but others ${ }^{3}$ had some teeth set in a bone groove (the pleurodont condition, seen in many living lizards). The teeth indicate various insectivorous and herbivorous diets.

Later sphenodontians of the Jurassic (144-208 million years ago) include longbodied marine animals ${ }^{4}$ which reached lengths of $1.5 \mathrm{~m}$; tiny terrestrial species less

Sphenodon punctatus from Stephens Island, New Zealand (Heather Angel). than $20 \mathrm{~cm}$ long; and bizarre Jurassic and early Cretaceous genera ${ }^{6,7}$ which had transversely broad teeth and were probably herbivores. The Sphenodontia of the Mesozoic were diverse, consisting of tiny insectivores, moderate-sized herbivores and several specialized marine forms.

It is clear that Sphenodon can no longer be treated as the last remnant of a lineage of living fossils. Several fossil sphenodontians show lizard-like characters that are absent in Sphenodon, whereas others developed unique specializations not seen in any other group. The Sphenodontia as a whole cannot be called living fossils by any definition, while Sphenodon itself can only be so described in terms of its present-day low diversity and restricted geographical distribution. It does not show primitive characters - Whiteside ${ }^{3}$ and $I^{8}$ estimated that Sphenodon displays almost 20 advanced features when compared with the nearest relatives of the Sphenodontia. It cannot have persisted unchanged for 100 200 million years. Michael J. Benton

\footnotetext{
1. Fraser, N.C. Palaeontology 25, 709 (1982); 27, 575 (1984); 29,165 (1986).

2. Carroll, R.L. Paleontographica A189, 1 (1985).

2. Carroll, R.L. Paleontographica A 189,1 (1985).
3. Whiteside, D.I. Phil. Trans. R. Soc. B312, 379 (1986)

4. Darwin, C. On the Origin of Species (Murray, London, 1859).

5. Schopf, T.J.M. A. Rev. Earth planet, Sci. 12, 245 (1984).

6. Throckmorton, G.S., Hopson, J.A. \& Parks, P. J. Paleontol. 55,586 (1981).

7. Rasmussen, T.E. \& Callison, J. Paleontol. 55, 1109 (1981). 8. Benton, M.J. Zool. J. Linn. Soc. 84, 97 (1985).
} 